\title{
Which Norwegian Enterprises Offer the Poorest and the Best Pension Entitlements? 1,2
}

\section{Tove Midtsundstad ${ }^{3}$}

Research professor, Fafo Institute for Labour and Social Research, Norway

\begin{abstract}
The National Insurance Scheme (NIS) remains the cornerstone of the Norwegian pension system. The introduction of a mandatory occupational pension in 2006, and the restructuring of the contractual pension (AFP) in 2008, have, however, significantly increased the importance of labor market based pensions. Entitlement to AFP and contributions to occupational pensions are largely determined by individual employers, thus resulting in significant different future pension benefits and opportunities to retire early among employees. This article investigates what characterizes private sector enterprises that offer their employees both entitlement to AFP and a 'good' occupational pension, compared with enterprises that only offer a minimum pension. Analyzing data from a survey carried out in 2012 among I 107 private sector companies, I find that companies who offered an occupational pension before such schemes became mandatory in 2006 and companies where the social partners had conducted negotiations concerning pensions, were more likely to offer 'good' labor market based pensions. Both of these factors are linked to union strength and strong social partner relations.
\end{abstract}

\section{KEYWORDS}

Defined contribution (DC) schemes / defined benefit (DB) schemes / occupational pensions / occupational welfare / pension reform

\section{Introduction}

rivate or funded pensions play an important role in the retirement income system of many OECD countries (OECD 2017) and this role is expected to grow, as recent pension reforms in many countries will lead to a reduction in public pension benefits. The private pensions employees are offered are also much more likely to be of the defined contribution (DC) type, meaning that individuals are more directly exposed to investment risk and bear the pension cost of living longer themselves (OECD 2012). When eligibility requirements and contribution rates are largely determined by individual employers, leading to wide disparities both within and between countries in terms of the coverage of private pension schemes and their value for employees, I find it interesting to investigate which employers offers the best and which the poorest employer-based pensions and the reasons for this (Wi 2015).

\footnotetext{
${ }^{1}$ You can find this text and its DOI at https://tidsskrift.dk/njwls/index.

${ }^{2}$ An earlier version of this paper was published in H. Dale-Olsen (red.), Norsk arbeidsliv i turbulente tider. Oslo: Gyldendal Akademisk (chapter 10, pp. 184-200).

${ }^{3}$ Corresponding author: Tove Midtsundstad, Fafo Institute for Labour and Social Research, P.box 2947 Tøyen, 0608 Oslo, Norway. E-mail: tim@fafo.no.
} 
Unlike Denmark, where occupational pensions have long been an integrated part of the collective agreement systems and cover over $90 \%$ of all employees, and Sweden which has a mandatory second pillar for all wage earners (Chen \& Beetsma 2015), the occupational pension system in the private sector in Norway was a voluntary system until 2006, whereby the enterprise themselves decided whether or not they should offer their employees a supplementary pension. As a consequence, only half of all Norwegian employees in the private sector were entitled to an occupational pension before 2006, and the entitlement was unequally distributed among employees (Pedersen 2000; Midtsundstad \& Hippe 2005). In 2006, however, Norway moved from this voluntary system to a mandatory occupational pension system allowing tax reliefs on contributions both to DC and defined benefit (DB) schemes. Today, all Norwegian employees are entitled to an occupational pension (Veland 2014). However, to a large degree, the enterprises still decide on the level of contribution. Furthermore, having access to the contractual pension (AFP), which from 2011 is a lifelong, supplementary pension (equal to a DC scheme with a savings rate of $2.8 \%$ of salary each year), has become more important than ever for Norwegian employers' income in old age, as the expected benefits from public pensions will decrease for younger cohorts (Hippe et al. 2018). However, there is still little knowledge on how different contribution rates are distributed among different enterprises and groups of employees in the private sector. The aim of this article is to map the current coverage of different occupational pension schemes and AFP in the private sector in Norway and outline what characterizes enterprises that offer the best and the poorest employer-based pensions.

Before presenting previous research and theory, data, and results, I shall give a brief overview of the Norwegian pension system and changes in private pension regulations over the last 17 years.

\section{The Norwegian pension system}

The Norwegian pension system is a three-pillar system where the National Insurance Scheme (NIS) old-age pension has traditionally been the main source of income for most people in their old age. Since the introduction of the mandatory occupational pension in 2006, all employees are also covered by an occupational pension scheme. Previously, only public-sector employees and around half of all private-sector employees were covered by such schemes. Furthermore, until 2001, there were only DB schemes in the private sector. In the public sector, this is still the case, although a new public DC scheme will be implemented in 2020. In addition, since 1989, all civil servants (employees in the local government and state sector), and private sector employees covered by a collective wage agreement, ${ }^{1}$ have been entitled to a contractual early retirement pension (AFP pension), which has given them the opportunity to draw an old-age pension before the age of 67 and retire.

As part of the Norwegian pension reform, changes have been made to the NIS oldage pension and disability pension, to the laws regulating occupational pension schemes in the private sector, and to the contractual early retirement scheme (the AFP scheme) in the private sector (Midtsundstad 2014). An important feature of the Norwegian pension reform is flexible retirement starting at the age of 62 based on actuarial principles, which means that the earlier you draw your pension the less you get each year. On the other

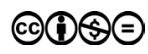


hand, drawing a pension early no longer results in reduced pension payments for those still working. The old-age pension is also adjusted in line with average life expectancy to ensure that the pension system remains sustainable and can be seen as a substitute for an increase in the statutory pension age. In order to preserve the value of earned pension rights, the old-age pension is also adjusted each year in line with the average wage increase in Norway. During the payment period, annual adjustments are made in line with the average wage increase and then reduced by $0.75 \%$.

In addition, the AFP scheme in the private sector, which is part of the sector's collective wage agreements, was changed from an early retirement scheme to a supplementary old-age pension in the 2008 bargaining round (and implemented in 2011). Prior to this, it was only those who retired between the ages of 62 and 67 who received an AFP pension. Today, all employees covered by the scheme are entitled to a lifelong supplementary pension, whether they retire early or not. The new AFP scheme in the private sector follows the same principle of actuarial neutrality as the NIS old-age pension. However, to receive an AFP pension, the individual must be working in a company covered by a collective wage agreement when they retire. If an employee moves from a company with an AFP scheme (covered by a collective wage agreement) to a company without an AFP scheme (not covered by a collective wage agreement) at age 60 or 61, for example, they will lose their right to the AFP pension even if they worked in a company with an AFP scheme up to that date.

The NIS old-age pension and AFP pension can today be drawn from the age of 62 , whether the person continues working or not. The precondition is that the accumulated pension entitlements exceed the minimum pension level, ${ }^{2}$ after adjustments are made based on changes in life expectancy. Continued employment after the age of 62 will also result in the accumulation of increased pension entitlements (up to the age of 75) and thus a higher annual pension when it is finally drawn. However, flexible retirement in Norway is not a possibility for all older workers. A large number of women in the private sector with low wages, many years in part-time work and no AFP pension are not entitled to draw a full old-age pension from the age of 62 , as they have not accumulated a pension entitlement, which exceeds the annual minimum pension level (LO \& NHO 2017).

As earlier mentioned, since 2006, all employers have been obliged to offer their employees an occupational pension scheme. As a result, there has been a huge increase in the number of employees covered by DC schemes and many employers have chosen to end their DB schemes and replace them with far less generous DC schemes. Today, around $80 \%$ of all employees in the private sector are covered by DC schemes (Veland 2014). In other words, the occupational pensions market in the Norwegian private sector has undergone major changes since the turn of the millennium. Although the NIS retirement pension remains the cornerstone of the Norwegian pension system, the introduction of a mandatory occupational pension (OTP) in 2006, and the restructuring of the AFP pension scheme in 2008, have helped increase the significance of labor market based pensions. The type of occupational pension offered and entitlement to an AFP pension have thereby become more important than ever for the level of future pension benefits and the opportunity for employees in the private sector to retire aged 62 . According to Hippe, Hammer and Vøien (2018) expected replacement rates for those born in 1963 will vary from approximately $52 \%$ for those without AFP and an occupational pension at a minimum level, to $72 \%$ for those having both AFP and a good occupational pension. 
In general, state regulations influence the scope of occupational pensions as well as the preferences of employers and trade unions (Shalev 1996; Trampusch 2013). The regulations for occupational pensions (DC schemes) in the private sector in Norway only stipulate the minimum and maximum rates for the annual contributions. As such, the regulations permit large variations in occupational pension entitlements between enterprises and groups of employees. Since the details of schemes are determined by the individual employer, and the schemes are rarely included in collective agreements (Barth \& Nergaard 2015), the employer ultimately decides on the rate of contributions. The employer, however, has to offer the same scheme to all his employees. The minimum DC schemes in 2012 only guaranteed that the employer contributes $2 \%$ of the employee's income between 1 and $6 \mathrm{G}$ ( $\mathrm{G}=$ base amount $=95800-574800$ NOK in 2018) every year, ${ }^{3}$ which amounts to a rather small supplement to the NIS old-age pension according to an estimate of expected pension benefits for future generations (Hippe et al. 2018). Employers also decide whether the accumulated pension capital and disbursements should be regulated at a specific rate (guaranteed yield) or follow fluctuations in the stock market. In case of the latter, each employee may determine the risk profile (high, medium, or low), but very few employees actively make such choices (Midtsundstad \& Hyggen 2011). Most employees, including younger cohorts, therefore have a medium or low risk profile on their pension savings.

Given the growing importance of supplementary pension schemes in Norway and other European countries (Trampusch 2009), along with an increased heterogeneity of possible occupational pension schemes and contribution rates and thus benefit levels, it is interesting to examine more closely the distribution of different schemes within countries and between enterprises (Wi $\beta$ 2015). The aim of this article is to investigate what characterizes Norwegian private sector enterprises that offer the best and the poorest employer-based pensions, respectively.

\section{Earlier research}

According to Wi 3 (2015), studies analyzing welfare have previously focused on countries as units, taking only one pension scheme or the average representing the countries. An important goal of the article is to identify some of the factors that seem to affect the variation in enterprises' occupational pension schemes within countries.

Literature focuses on several different factors when trying to explain the differences between countries, sectors and enterprises in terms of occupational welfare: the skills of employees, the power resources of trade unions, type of industry and sector, size of the enterprise, etc. (Brigden \& Meyer 2005; Freeman 1981; Greve 2007; Gustman et al. 1994; Ippolito 1991; Leigh 1981; Mares 2003; McCarthy 2006; Natali et al. 2018; Seeleib-Kaiser et al. 2012; Trampusch \& Eichenberg 2012; Wi $\beta$ 2015).

Most economic studies have investigated why some companies offer an occupational pension plan while others do not, and less on the variation in enterprises' contributions to pension plans. The main behavioral motivations for enterprises to offer a pension plan, as summarized by Gustman et al. (1994), are to regulate work effort, turnover other than retirement, retirement, and worker quality, and thereby cut labor costs and raise productivity. However, there are few studies that have been able to test how pensions (deferred payment) affect worker effort or productivity (ibid.).

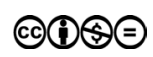


Enterprises facing substantial hiring and training costs may, however, find it profitable to discourage turnover by offering pension plans. Allen, Clark, and McDermed (1993) found that worker turnover was much lower among workers covered by pensions than workers without pensions. The main factors responsible for lower turnover were capital losses in pension wealth (exit costs for workers who leave the enterprise), in addition to self-selection and compensation levels.

Enterprises with high training costs might also be more likely to offer pension programs than enterprises that invest less in their employees in order to attract and keep particular employees - 'stayers' instead of 'movers' (Ippolito 1991, 1992). In addition, pension plans can be an instrument for enterprises to control retirement flows, as workers with generous pensions retire earlier than those with lower pension benefits (Gustman et al. 1994).

According to economic theory, pensions can also constitute an advantage in the competition for labor (see, e.g., McCarthy 2006). Pensions, especially DB schemes, might also be a more important way for enterprises to obtain long-term commitment from workers than wage tilt (Ippolito 1991). Enterprises that employ highly and specifically qualified employees, who are of high value, especially in times of labor shortage, might therefore offer occupational welfare to attract employees and bind them to the enterprise (Wi $\beta$ 2015). In other words, skills can materialize in terms of employee power vis-à-vis the employer, which in term can be used to ask for additional benefits such as better occupational pensions. Hence, research has found that coverage tends to be high in enterprises that predominantly rely on highly skilled employees and low in enterprises that predominantly rely on a workforce requiring low general skills (Seeleib-Kaiser et al. 2012; Wiß 2015).

Furthermore, several studies have found that strong trade unions are more likely to be successful in negotiating with employers about occupational pensions than weak trade unions (Wi $\beta$ 2015). By contrast, the lack of both employees with high and specific skills and strong trade unions will, according to Wi $\beta$ (2015), often result in occupational pension schemes with low employer contributions. Freeman (1981), who studied the impact of unions on employer fringe benefit costs, also found that unions increase the ratio of fringe benefits to wages, especially expenditures that represent deferred forms of compensation, such as pensions. A study by Leigh (1981), on the other hand, showed that unions play an important role in extending the coverage of private pension programs, although unionized workers eligible for a pension expected to receive less in retirement benefits than nonunion workers.

In addition, companies may also be interested in using occupational welfare in exchange for wage moderation, and as a way to reduce costs and thereby achieve international competitiveness (Natali et al. 2018). Earlier research has found that highly profitable and export-oriented industries tend to offer more generous occupational welfare schemes more frequently than companies primarily producing for the domestic markets (Ibid). Company size has also been a common explanation for occupational welfare: small and medium sized enterprises offer less generous occupational welfare schemes than large companies (Mares 2001; Trampusch \& Eichenberger 2012).

Studies of occupational pensions in Norway have also found that the size of enterprises, employee skills, and trade union power have an impact on occupational pension coverage (Midtsundstad \& Hippe 2005; Hernæs et al. 2011; Pedersen 2000). According to previous analyses, such schemes were less prevalent in small enterprises than in large 
ones (Hernæs et al. 2011; Midtsundstad \& Hippe 2005). Before 2006, less than half of all private-sector employees in Norway were entitled to an occupational pension. In most cases, these were DB schemes and guaranteed the employee a total pension equivalent to $66 \%$ of their final salary or more (Pedersen 2000; Midtsundstad \& Hippe 2005). Furthermore, occupational pension schemes in Norway before 2006 were more frequently found in sectors such as health care, education and research, transport and telecommunications than in the hotel/catering or construction industries (Midtsundstad \& Hippe 2005). Occupational pension schemes in 2003 in Norway were also more widespread in enterprises with well-established social partner relations than in enterprises with low unionization rates and no collective agreements (Midtsundstad \& Hippe 2005; Hernæs et al. 2011), thus corroborating previous studies (Pedersen 2000; Hippe $\&$ Pedersen 1992). The likelihood of having an occupational pension scheme was also higher in enterprises that were exposed to limited competition in their markets for goods or services, and also in enterprises that had a greater degree of numerical flexibility (Midtsundstad \& Hippe 2005). Furthermore, occupational pensions in Norway were typically found in enterprises with decentralized wage negotiations and the requirement for long training, and were associated with tax gains (both for employees and employers) and expected increases in average tenure (Hernæs et al. 2011).

Although occupational pensions became mandatory in Norway in 2006, and most Norwegian employees are today entitled to an occupational pension, it is still interesting to investigate which factors might explain the variation in employers' contributions to occupational pension schemes. My main hypothesis is that the size of the enterprise, employee skills, training costs, and trade union power also play an important role in deciding who gets the best and who gets the poorest occupational pensions. Building on earlier analyses, this article investigates whether the distribution of 'good' and 'poor' occupational pensions in current working life in Norway follows traditional patterns, as described above. I ask whether variations in the coverage of different DC and DB schemes and contribution rates are a result of differences in the size of enterprises, differences in the skills of their employees, training costs, the enterprise's need for labor and the recruitment situation, differences in their economic situations, differences in the strength and bargaining power of local trade unions, as well as in enterprises' history and the tradition of offering occupational welfare.

\section{Data and methodology}

The analyses in this article are based on data from an enterprise survey (Arbeids- og bedriftsundersøkelsen 2012 - ABU2012) conducted in 2012 by Statistics Norway (SN) combined with individual register data from SN on all employees in the participating enterprises. ABU2012 contacted a representative sample of 3519 private and public enterprises with more than ten employees, of which 1888 enterprises participated (response rate: $53.7 \%$ ). The sample was stratified according to enterprise size, year it was established, and private and public sector. I therefore use sampling weights estimated by SN when analyzing data (Holmøy 2013). In this article, we only use data from the private sector $(\mathrm{N}=1107)$, since all public sector employees in 2012 had a DB scheme guaranteeing a pension from age 67 equal to $66 \%$ of their last salary (given 30 years' tenure in the public sector).

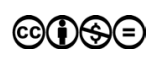


The survey consisted of telephone interviews with the managing directors and included, among other things, the coverage of collective agreements, the coverage of different occupational pension schemes (DC, DB, and AFP) including benefit levels/contribution rates, whether trade union members were involved in changing the pension schemes, the size of the enterprise, whether the employers are organized and the percentage of employees organized, and a range of other company characteristics (see Holmøy 2013 \& Dale-Olsen 2015 for an extended documentation of the survey).

Examining pension entitlements as a whole, I investigate the proportion of enterprises that provide 'good', 'moderate', and 'poor' employer-based pensions, respectively (Table 1).

Table I Definition of 'good','moderate', and 'poor' employer-based pensions.

\begin{tabular}{|c|c|c|c|}
\hline & AFP & DC & DB \\
\hline \multirow[t]{2}{*}{ 'good' } & Yes & $\begin{array}{l}\text { Contribution }>2 \% \text { of annual } \\
\text { income beyond I G }\end{array}$ & \\
\hline & Yes & & $\begin{array}{l}\text { Benefit } \geq 66 \% \text { of final salary (incl. old } \\
\text { age pensions from NIS) }\end{array}$ \\
\hline \multirow[t]{4}{*}{ 'moderate' } & Yes & $\begin{array}{l}\text { Contribution }=2 \% \text { of all annual } \\
\text { income up to } 6 \mathrm{G} / \text { between } \\
\text { I and } 6 \mathrm{G} / \text { do not know the } \\
\text { contribution level }\end{array}$ & \\
\hline & Yes & & $\begin{array}{l}\text { Benefit }<66 \% \text { of final salary (incl. } \\
\text { old age pensions from NIS) / do not } \\
\text { know the benefit level }\end{array}$ \\
\hline & $\begin{array}{l}\text { No/do not } \\
\text { know }\end{array}$ & $\begin{array}{l}\text { Contribution }>2 \% \text { of all annual } \\
\text { income up to } 6 \mathrm{G} / \text { between I } \\
\text { and } 6 \mathrm{G}\end{array}$ & \\
\hline & $\begin{array}{l}\text { No/do not } \\
\text { know }\end{array}$ & & $\begin{array}{l}\text { Benefit } \geq 66 \% \text { of final salary (incl. old } \\
\text { age pensions from NIS) }\end{array}$ \\
\hline \multirow[t]{2}{*}{ 'poor' } & No & $\begin{array}{l}\text { Contribution }=2 \% \text { of all annual } \\
\text { income up to } 6 \mathrm{G} / \text { between I } \\
\text { and } 6 \mathrm{G}\end{array}$ & \\
\hline & No & & $\begin{array}{l}\text { Benefit }<66 \% \text { of final salary (incl. old } \\
\text { age pensions from NIS) }\end{array}$ \\
\hline
\end{tabular}

Notes: $\mathrm{G}=$ base amount $=95,800$ NOK in 2018 .

Enterprises with 'good' employer-based pension schemes are defined as those offering an AFP pension together with either a DC pension above the minimum level $(2 \%)$ for income up to $6 \mathrm{G}$, or a DB pension providing $66 \%$ or more of the final salary. Enterprises that offer no entitlement to an AFP pension and have a DC scheme with a $2 \%$ contribution for income up to $6 \mathrm{G}$, or a DB pension scheme with a yield of $65 \%$ or less, are designated as enterprises offering 'poor' pension schemes. Classified as offering 'moderate' schemes are those enterprises that either offer a DC pension above the minimum level, or a DB pension providing $66 \%$ or more of final salary, but do not know whether they offer an AFP pension or not; offer an AFP pension but a minimum DC pension ( $2 \%$ contribution) or a DB pension providing $65 \%$ or less; or enterprises where 
the managers did not know the occupational pension scheme's rate of contributions or level of benefits.

A total of $20 \%$ of the enterprises in our sample offer 'good' pension schemes. Together, these enterprises employ $18 \%$ of the total number of employees covered by the sample (Figure 1). A total of $26 \%$ of the enterprises, covering $19 \%$ of the employees, provide 'poor' pension schemes, while $63 \%$ of the employees are covered by so-called 'moderate' schemes.

Figure I Proportion of employees with 'good', 'moderate', and 'poor' labor-market based pension schemes, respectively. $\mathrm{N}=1$ 107. Weighted.

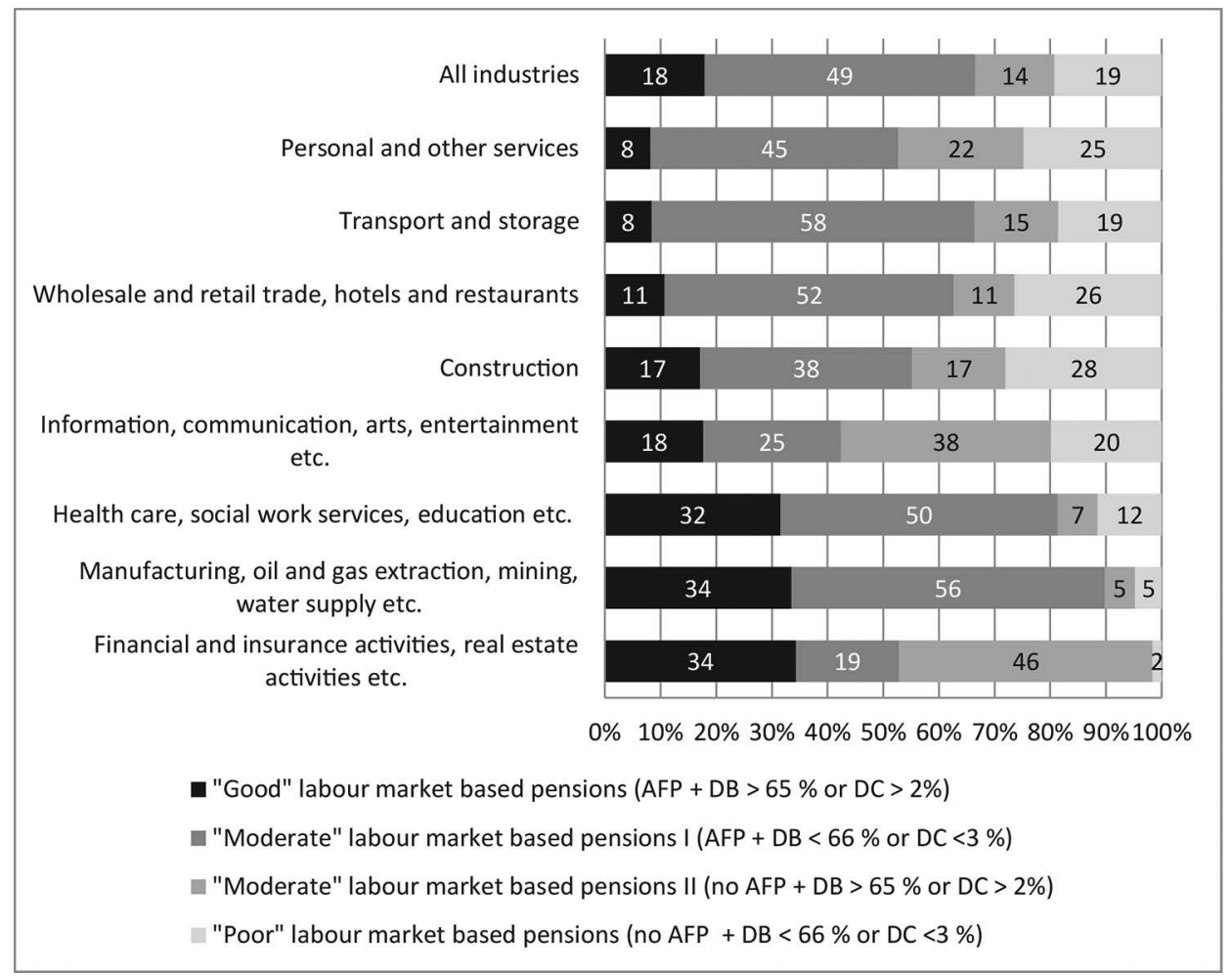

There is considerable variation between sectors (Figure 1). Entitlement to an AFP pension scheme and an occupational pension scheme above the minimum level ('good' schemes) is most common in private enterprises in the finance and insurance sectors (where $34 \%$ of employees are eligible to receive this combination of schemes), in manufacturing (also where 34\% of employees are eligible for such schemes), and in education, health, and social services in the private sector (where $32 \%$ of employees are covered by such schemes). Those sectors with the fewest 'good' schemes are retail, hotel, and catering, where only $11 \%$ of employees have 'good' pension entitlements, the transport and storage sectors and other private sector services, where these entitlements only apply to $8 \%$ of employees. 
The majority of employees with 'poor' pension entitlements work in the construction sector (covers $28 \%$ of the total number of employees), in the retail, hotel, and catering sectors ( $26 \%$ of employees), and in other private sector services (25\% of employees). The lowest number with 'poor' pension entitlements are found in the finance and property sectors $(2 \%)$ and in manufacturing $(5 \%)$. The fact that few employees in these industries have poor entitlements must be seen partly in the context of the manufacturing sector's strong collective agreement coverage and hence its AFP pension scheme coverage.

To obtain a clearer picture of which factors might increase the likelihood of an enterprise offering 'good' or 'poor' pension schemes to their employees, I performed a selection of regression analyses. Specifically, I examined whether and to what extent social partner relations, globalization and the situation with regard to competition, and recruitment and workforce composition increase the likelihood that an enterprise will have a) an AFP scheme in combination with a DC pension scheme above the minimum level $(2 \%)$ or a DB scheme that pays out a benefit corresponding to $66 \%$ or more of final salary $(=1)$ or not $(=0)$; b) no AFP scheme in combination with a DC scheme at the minimum level $(2 \%)$ or a DB pension scheme that pays out a benefit corresponding to $65 \%$ of final salary or less $(=1)$ or not $(=0)$.

To take account of social partner relations in the analyses, I investigated whether strong social partner relations $(0=$ no, $1=$ yes $)$, social partners that have conducted a pension negotiation process $(0=$ no, $1=\mathrm{yes})$, an occupational pension scheme established before 2006 ( $0=$ no, $1=$ yes), and occupational pension scheme has been changed since 2001 ( $0=$ no, 1 = yes) have an effect on pension entitlements.

The importance of globalization and competition is measured by examining whether the enterprise has foreign owners $(0=$ no, $1=y e s)$, its main market is outside the Nordic countries $(0=$ Norway and the Nordic countries, $1=$ the rest of the world); and whether it is exposed to strong competition in the product/services market (1=strong or fairly strong, $0=$ fairly or very little).

The effect of the recruitment situation is measured by examining workforce requirements in the short term $(1=$ need to increase, $0=$ unchanged or reduced $)$, and the recruitment situation for the main occupational group (very or fairly difficult $=0$, very or fairly easy $=1$ ).

Since the costs related to DB pension schemes increase with the number of older employees working in the enterprise, I have controlled for the proportion of employees aged 55 years and over ( $0=$ less than $40 \%, 1=40 \%$ or more). Similarly, I include the use of temporary employees $(0=$ no, $1=y e s)$, as only permanent employees are entitled to subscribe to the enterprise's pension scheme. Widespread use of temporary employees may therefore help increase the likelihood of having good pension entitlements for the core workforce and reduce the likelihood of having poor entitlements.

In all the analyses, I control for industry sector (1=manufacturing, $2=$ construction, $3=$ retail, hotel and catering, $4=$ transport and storage, $5=$ information, communication, culture and entertainment, $6=$ finance and insurance, real estate, etc., $7=$ other services, $8=$ education, health, and social services (ref.)), size of the enterprise $(1=10-19,2=20-49$, $3=50-99,4=100-199,5=200$ etc. $=$ ref $)$, main occupational group in the enterprise $[1=$ academic occupations, $2=$ office, sales, and service occupations, $3=$ blue-collar occupations (ref.)], proportion of employees with university level education ( $0=$ less than $50 \%$ with higher education, $1=50 \%$ or more with higher education), and year the enterprise was established ( $1=$ after $2001,0=2001$ or earlier). 
Table 2 summarizes the distribution of the independent variables, and the bivariate correlation between each individual variable and the dependent variable. I have also checked whether there are strong correlations between the independent variables (not shown), and the Pearson $r$ was rather small $(<0.3)$. Hence, I will assume that collinearity is no problem in the multivariate analysis.

The bivariate analyses (Table 2) show that strong social partner relations, having negotiated on occupational pensions (OP), having offered OP before it became mandatory in 2006 and having changed the pension schemes after 2001 are all factors that increase the probability of an enterprise offering 'good' pension entitlements. Furthermore, having a foreign owner decreases the likelihood of offering a 'good' pension, while having the main market outside the Nordic countries increases the likelihood of enterprises offering 'good' pension entitlements. On the other hand, all the other coefficients seem to have no significant impact on the likelihood of offering 'good' pensions. In accordance with this, the same factors which increase the probability of offering 'good' pension entitlements seem to decrease the likelihood of offering 'poor' pension entitlements. However, having one's main market outside the Nordic countries seem to increase the probability of offering both 'good' and 'poor' pension entitlements. In addition, strong competition in the market does not correlate with offering a 'poor' pension, but increases the likelihood of enterprises offering 'good' pension entitlements.

Table 2 Overview of the independent variables and the bivariate coefficients $(\operatorname{Exp}(B))$. Weighted. $N=1107$

\begin{tabular}{|c|c|c|c|}
\hline & $\begin{array}{c}\text { Share of } \\
\text { enterprises (\%) }\end{array}$ & $\begin{array}{l}\text { 'Good' pensions } \\
\text { Exp(B) }\end{array}$ & $\begin{array}{c}\text { 'Poor' pensions } \\
\text { Exp(B) }\end{array}$ \\
\hline \multicolumn{4}{|l|}{ Social partner relations } \\
\hline $\begin{array}{l}\text { Strong relations between social } \\
\text { partners }\end{array}$ & 36.2 & $3.985^{*}$ & $0.170 *$ \\
\hline $\begin{array}{l}\text { Have negotiated on occupational } \\
\text { pension (OP) }\end{array}$ & 12.1 & $2.869 *$ & $0.384 *$ \\
\hline Offered OP before 2006 & 42.1 & $2.337 *$ & $0.337 *$ \\
\hline Changed the OP scheme after 2001 & 21.5 & $\left.1.67\right|^{*}$ & $0.418 *$ \\
\hline \multicolumn{4}{|l|}{$\begin{array}{l}\text { Globalization and market } \\
\text { situation }\end{array}$} \\
\hline Foreign owner & 12.0 & $0.529 *$ & 1.392 \\
\hline $\begin{array}{l}\text { Main market outside the Nordic } \\
\text { countries }\end{array}$ & 6.4 & $2.210^{*}$ & $1.576 *$ \\
\hline $\begin{array}{l}\text { Market situation - self-rated strong } \\
\text { competition }\end{array}$ & 83.5 & 1.470* & 1.232 \\
\hline \multicolumn{4}{|l|}{ Recruitment situation } \\
\hline $\begin{array}{l}\text { Need for more labor in the next } \\
12 \text { months }\end{array}$ & 31.3 & 1.023 & 1.103 \\
\hline Easy to get competent labor & 42.9 & 1.327 & 0.810 \\
\hline
\end{tabular}




\begin{tabular}{llll}
\hline & $\begin{array}{c}\text { Share of } \\
\text { enterprises (\%) }\end{array}$ & $\begin{array}{c}\text { Good' pensions } \\
\text { Exp(B) }\end{array}$ & $\begin{array}{c}\text { 'Poor' pensions } \\
\text { Exp(B) }\end{array}$ \\
\hline Cost & & & 1.143 \\
Share of older workers $55+(>40 \%)$ & 17.4 & 1.406 & 0.946 \\
$\begin{array}{l}\text { Share of temporary employees } \\
(>20 \%)\end{array}$ & 15.0 & 0.869 & 1.033 \\
\hline $\begin{array}{l}\text { Type of labor } \\
\text { Share of highly skilled employees }\end{array}$ & 34.4 & 1.083 & \\
$\begin{array}{l}(>50 \%) \\
\text { Core employees = blue-collar workers } \\
\text { (ref.) }\end{array}$ & 22.6 & & \\
Academic occupations & & & 0.915 \\
Sales and service occupations & 47.7 & 1.271 & 1.321 \\
$\mathrm{~N}$ & 29.7 & 0.703 & \\
\hline
\end{tabular}

Notes: I. $* \mathrm{p} \leq 0.05$.

\section{Results}

The results of the logistic regression analyses (the average marginal effects and robust standard deviations) are presented in Table 3. The marginal effects for the control variables (industry, size of the enterprise, and year the enterprise was established) are not shown.

Table 3 Characteristics of enterprises that offer 'good' and 'poor' pension entitlements. Weighted figures. Marginal effects and robust standard deviations

\begin{tabular}{|c|c|c|}
\hline & 'Good' pensions & 'Poor' pensions \\
\hline \multicolumn{3}{|l|}{ Social partner relations } \\
\hline Strong relations between social partners & $0.0017(0.00783)$ & $-0.0015(0.0099)$ \\
\hline Have negotiated on occupational pension (OP) & $0.1365(0.37834)$ & $-0.1829(0.0730)$ \\
\hline Offered OP before 2006 & $0.0989(0.33527)$ & $-0.1918(0.0396)$ \\
\hline Changed the OP scheme after 2001 & $0.0489(0.03609)$ & $-0.0821(0.5318)$ \\
\hline \multicolumn{3}{|l|}{ Globalization and market situation } \\
\hline Foreign owner & $-0.0698(0.0658)$ & $0.0309(0.0567)$ \\
\hline Main market outside the Nordic countries & $0.1238(0.5001)$ & $0.0495(0.0637)$ \\
\hline Market situation - self-rated (ref.=strong competition) & $0.0623(0.0422)$ & $0.0645(0.0449)$ \\
\hline \multicolumn{3}{|l|}{ Recruitment situation } \\
\hline Need for more labor in the next 12 months & $0.0076(0.0362)$ & $0.0175(0.0389)$ \\
\hline Easy to get competent labor & $0.0425(0.3354)$ & $-0.0413(0.0368)$ \\
\hline
\end{tabular}


Table 3 (Continued)

\begin{tabular}{lcc}
\hline & Good' pensions & Poor' pensions \\
\hline Cost & & \\
Share of older workers $55+(>40 \%)$ & $0.4815(0.0408)$ & $-0.0093(0.0456)$ \\
Share of temporary employees $(>20 \%)$ & $-0.0359(0.0508)$ & $-0.0065(0.0507)$ \\
\hline Type of labor & & \\
Share of high skilled employees $(>50 \%)$ & $-0.0342(0.0413)$ & $0.0543(0.0467)$ \\
Core employees = blue-collar workers (ref.) & $-0.0312(0.0275)$ & $0.0397(0.0266)$ \\
$\mathrm{N}$ & 988 & 988 \\
\hline
\end{tabular}

Notes:

I. In all the analyses, I controlled for industry, size of the enterprise, and whether the enterprise was established before or after 2001 .

2. Emphasized in bold = significance level of $10 \%$ or less.

3. Due to lack of information on some of the independent variables $N=988$.

The analyses show that the probability of an enterprise offering its employees 'good' pension entitlements still increases if the enterprise's occupational pension scheme was established before 2006, and if the enterprise negotiated with its employees on pensions during the last two years. A main market outside Norway and the Nordic countries also increases the likelihood of the enterprise offering 'good' labor market based pensions. However, after controls for the other independent variables in the model, strong social partner relations are no longer significant, and neither is having a foreign owner. This is also the case with regard to competition in the product/ service market, recruitment situation, and workforce requirements. The same applies to workforce characteristics such as proportion of employees with higher education, proportion of employees over 55 years of age, and the enterprise's use of temporary employees. The age of the enterprise does, however, reveal something (not shown in Table 2), since enterprises that were established before 2001 offer better pension entitlements than those established later. Industry sector, on the other hand, has no effect, nor does the size of the enterprise measured as the number of employees.

If we look at the likelihood of an enterprise offering its employees 'poor' pension entitlements, this still decreases if the occupational pension scheme was established after 2006, and if pensions have been negotiated during the last two years. Strong social partner relations in themselves, however, are of no significance in the multivariate analysis, nor are any of the other factors examined, that is, competition in the product and/or service market, foreign ownership, main market within or outside the Nordic countries, recruitment situation and workforce requirements, type of workforce, proportion of employees with higher education, and proportion of older employees.

\section{Discussion}

What primarily characterizes Norwegian enterprises that offer 'good' occupational pensions are the fact that they offered their employees an occupational pension before this became mandatory in 2006. This may indicate that well-established enterprises, 
which have long prioritized occupational pensions for their employees, do not choose to weaken the conditions of their pensions. In other words, already established, good schemes are not very easy to change, even when the regulations changed and opened up for DC schemes. This is in line with other studies (Hippe \& Midtsundstad 2016), showing that enterprises who change from DB to DC schemes in most cases offer saving rates well above the minimum level. As other studies have shown (Hernæs et al. 2011; Midtsundstad \& Hippe 2005), strong social partner relations were also an important factor in explaining whether a company offered occupational pensions or not before it became mandatory. We may then indirectly also be measuring union strength. However, the correlation may also be an indicator that these enterprises have been doing well for a long time, as they offered an occupational pension scheme before this became mandatory, and that they are still financially healthy, as they still offer good pension conditions. Yet, the correlation might also be attributable to the fact that many enterprises sat on the fence in 2012 when there were still doubts regarding the quality of the DC schemes that could be offered. A considerable proportion of the enterprises that still reported having a 'good' DB scheme in 2012 may well have been opting to take a 'wait-and-see' approach. In other words, based on the data from 2012, it is probably too early to draw any final conclusions regarding the effect of the restructuring of occupational pension regulations on pension conditions for private sector employees in the long term.

In contrast to the findings of previous analyses (e.g., Midtsundstad \& Hippe 2005) and the bivariate analyses (Table 2), the multivariate analyses show that strong social partner relations in the form of a high level of unionization and local agreements at the enterprise level no longer have an impact on the pension conditions at the enterprise level. As mentioned earlier, the explanation for this rather surprising result might be that the importance of strong social partner relations is now mediated through the factor 'offered an occupational pension scheme before 2006' that, based on earlier studies, is correlated with strong social partner relations (Midtsundstad \& Hippe 2005; Hernæs et al. 2011). In addition, the fact of having negotiated on pension conditions increases the likelihood of enterprises offering 'good' pension entitlements. This indicates that cooperation between the social partners locally may be an important factor for the levels of occupational pension benefits and contributions. The fact that pension conditions are subject to negotiation in some companies even though the occupational pension scheme falls within the employer's remit, and that very few enterprises had included the occupational pension scheme in their collective agreements indicate that the enterprises' owners and management teams have been willing to allow the codetermination of the trade unions and to take account of their demands, that is, that they place an emphasis on good social partner relations.

Globalization in the form of an international market also appears to be of some importance. The same does not apply to foreign ownership and strong competition in the product/services market. It is nonetheless rather surprising that the enterprises that have their main market outside the Nordic countries are those that offer the best pensions. The reason may be that markets outside the Nordic countries in most cases is the rest of Europe where labor market based pension schemes are relatively widespread and hence also represent a cost for competitors. In addition, some enterprises may also use occupational pensions in exchange for wage moderation to reduce costs and thereby achieve international competitiveness (Natali et al. 2018). 
According to economic theory, pensions can constitute a competitive advantage in the competition for labor (see, e.g., McCarthy 2006). However, the analyses indicate that Norwegian enterprises do not widely use an offer of 'good' pensions to attract competent labor, since enterprises in need of more employees in the short term and those that have problems recruiting qualified labor are neither more nor less likely to offer 'good' pension conditions than those that have no need for more employees and/ or experience few problems with recruitment. This may be associated with the relatively limited knowledge of labor market based pensions among the population (Hermansen \& Midtsundstad 2013). Norwegian enterprises may therefore realize that there is little to be gained from offering 'good' but costly pension schemes as a means of attracting and retaining competent labor.

The composition of the workforce when it comes to types of core labor (be these white-collar or blue-collar workers), a large proportion of employees over the age of 55 , and a large proportion of employees with higher education, also appears to have little significance. This lack of importance of the age composition of the workforce may be associated, on the other hand, with the fact that a fairly large number of enterprises that previously offered DB schemes have now replaced these with DC schemes. Hence, enterprises' pension costs do not increase with increasing age as they did previously. Nor does the use of temporary employees increase the likelihood of the core workforce having 'good' pension conditions, which was the hypothesis.

Previous analyses have shown that primarily those with a higher education background were covered by occupational pension schemes in the private sector before 2006 (Midtsundstad \& Hippe 2005). However, employing a high proportion of employees with higher education does not appear to increase the likelihood of enterprises offering 'good' pension conditions in 2012. This does not necessarily mean that enterprises with highly skilled employees no longer offer better occupational pensions than enterprises where the majority of employees have a lower level of education. Rather, the most likely explanation is that many typical enterprises with highly educated employees (e.g., ICT companies) are not part of collective agreements which include AFP. The same reasoning might also explain the absence of any correlation between the type of core workforce and occupational pension conditions. Although enterprises whose core workforce consists of white-collar workers have better occupational pensions than enterprises primarily employing blue-collar workers or that offer positions in office, sales, and service work, access to AFP is more widespread in manufacturing and the transport and storage industry (mainly employing blue-collar workers) than in enterprises that mainly employ white-collar workers. The reason is that access to AFP schemes is not dependent on the bargaining power of local trade unions but rather on the bargaining power of trade unions nationally; hence, AFP is more equally distributed among enterprises with a different skills composition than 'good' DC and DB schemes. This also illustrates how important trade union power and collective agreed pensions at the national level are in securing a decent pension level for low skilled workers (Natali et al 2018).

\section{Conclusion}

The occupational pension system in the private sector in Norway has undergone considerable change since the turn of the millennium. Although the NIS pension is still 
the cornerstone of the Norwegian pension system, the introduction of the mandatory occupational pension in 2006, and the restructuring of the AFP scheme in the private sector in 2008 (with effect from 2011) have increased the importance of employer-based pensions. The type of occupational pension, level of contribution, as well as the entitlement to an AFP pension are now of increased importance with regard to the pension that individuals can expect to receive, when they can start to draw their pension, and when they can retire.

At the turn of the millennium, only half of all private-sector employees had an occupational pension scheme, and the majority had a scheme that entitled them to a pension equivalent to $66 \%$ of their final salary (including the old age pension from the NIS) after 30 years of earnings. Today, everyone is entitled to an occupational pension, but the variation in schemes and levels of benefits is far greater. Almost one in four had a DB scheme in 2012, while two out of three had a DC scheme. However, the quality of DC schemes varies greatly, and the largest proportion of employees have a scheme at the minimum level, which only ensures annual savings equivalent to $2 \%$ of salary. This provides a relatively low supplementary pension to the old-age pension from the NIS.

A total of $59 \%$ of employees in private enterprises with 10 or more employees are, however, part of collective agreements and entitled to an AFP pension. It is interesting to note in this regard the important role of AFP and hence collectively agreed occupational pensions in securing a 'moderate' or 'good' pension in old age for blue-collar workers. This underscores, as earlier research also shows (Natalie et al. 2018), the importance of employees' collective power in securing all groups of employees an acceptable pension in old age, including low skilled groups with low individual bargaining power.

However, a high degree of unionization and local tariff agreements seem to have no bearing on the contribution level or benefit level of occupational pensions when controlling for other relevant factors, including whether or not the OP scheme was established prior to 2006. Nevertheless, according to earlier studies, strong social partner relations at the enterprise level increased the probability of companies offering an OP scheme before 2006, which in most cases implied that they were offering quite 'good' pension entitlements. Furthermore, if pension negotiations have taken place in the workplace during the last two years (prior to 2012), this also increases the likelihood of good occupational pension conditions being offered. It is reasonable to assume that this is more likely to happen in companies with strong social partner relations. Yet, it is also an indicator of good cooperation between the social partners or that management is attentive to the demands of trade unions, since occupational pensions fall within the employer's remit and such pension schemes are very rarely included in the collective agreement. History is also relevant, as enterprises that have historically had occupational pension schemes for their employees (before this became mandatory) also more frequently offer good pension conditions today.

Globalization and competition also appear to have some effect on pension conditions, since enterprises whose main market is international offer good occupational pension conditions more frequently than enterprises whose market is Norway and the Nordic countries.

Contrary to economic theory, however, 'good' pension entitlements do not appear to be used to retain and recruit employees in Norway, as an increased need for labor and/ or recruitment problems do not appear to have any bearing on the pension conditions 
offered by companies. This may be associated with people's limited knowledge of labor market based pensions, making the offer of a good pension ineffective for recruitment purposes or as an instrument for retaining competent employees.

\section{Acknowledgments}

This work was supported by The Research Council of Norway as part of the 'Interactions between national and labor market based pensions in Norway: pension outcomes and policy processes' project, grant number 238205.

\section{References}

Allan, S. G., Clark, R. L. \& McDermed, A. A. (1991). Pensions, Bonding, and Lifetime Jobs. Working Paper No. 3688, Cambridge, MA: National Bureau of Economic Research (NBER).

Barth, E. \& Nergaard, K. (2015). Kollektive partsforhold: Status Quo eller endring? [Industrial relations: Status Quo or change?] In: H. Dale-Olsen (ed.), Norsk arbeidsliv i turbulente tider, Oslo: Gyldendal Akademiske.

Bridgen, L. M. \& Meyer, T. (2005). When do benevolent capitalists change their mind? Explaining the retrenchment of defined-benefit pensions in Britain, Social Policy and Administration 39(7): 764-785. doi: https://doi.org/10.1111/j.1467-9515.2005.00468.x.

Chen, D. H. J. \& Beetsma, R. (2015). Mandatory participation in Occupational Pension Schemes in the Netherlands and other Countries. CESifo Working Paper, No. 4593.

Dale-Olsen, H. (2015). Arbeids- og bedriftsundersøkelsen 2012 (ABU2012) [The Employee and employer survey 2012], vedlegg 1. In: H. Dale-Olsen (ed.), Norsk arbeidsliv i turbulente tider, Oslo: Gyldendal Akademisk.

Freeman, R. (1981) The Effect of Unionism on Fringe Benefits. Industrial and Labor Relations Review 34(4):489-509. Available from: https://www.nber.org/papers/w0292.

Greve, B. (2007). Occupational welfare. Winners and Losers. Cheltenham: Edward Elgar Publishing Limited.

Gustaman, A. L., Mitchell, O. S. \& Steinmeier, T. I. (1994). The role of pensions in the labor market: a survey of the literature, ILR Review 47(3): 417-438. doi: https://www.jstor. org/stable/2524975.

Hermansen, ^̊ \& Midtsundstad, T. (2013). Kjennskap til arbeidsmarkedsbaserte pensjoner i privat sektor, Søkelys på arbeidslivet 30(1-2): 107-123.

Hernæs, E., Piggott, J., Zhang, T. \& Strøm, S. (2011). Occupational pensions, tenure, and taxes, Journal of Pension Economics and Finance 10(3): 435-456. doi: https://doi. org/10.1017/S1474747210000089.

Hippe, J. M., Hammer, H. \& Vøien, H. G. (2018). Nok pensjon? Etter pensjonsreformen: effekter av ny folketrygd, AFP og tjenestepensjoner [Adequate pensions? After the pension reform: Estimated effects of the new old age pension from the National Insurance scheme, AFP and occupational pensions]. Fafo-report 2018: 17, Oslo: Fafo Institute for Labour and Social Research. https://www.fafo.no/index.php/zoo-publikasjoner/fafo-rapporter/item/nok-pensjon.

Hippe, J. M. \& Pedersen, A. W. (1992) Når jobben betaler. En analyse av velferdsordninger i arbeidsmarkedet. [When the employer pays. An analysis of occupational welfare]. Fafo report 136. Oslo: Fafo. 
Holmøy, A. (2013). Arbeids- og bedriftsundersøkelsen 2012 [The Employee and employer survey 2012]. Dokumentasjonsrapport, SSB-notater 38/2013, Oslo: Statistics Norway.

Ippolito, R. A. (2002). Stayers as 'workers' and 'savers': towards reconciling the pensin-quit literature, The Journal of Human Resources 37(2):275-308.

Ippolito, R. A. (1991). Encouraging long-term tenture: wage tilt or pensions? ILR Review 44(3):520-535.

Leight, D. E. (1981). The effect of unionism on workers' valuation of future pension benefits, ILR Review 34(4):510-521.

LO \& NHO (2017). Evaluering av AFP i privat sektor [Evaluation of the contractual pension AFP in the private sector]. Rapport fra arbeidet. 7 Desember 2017. Available from: https:// lo.no/PageFiles/32588/Evaluering \%20av $\% 20 \mathrm{AFP} \% 20 \mathrm{i} \% 20$ privat $\% 20$ sektor $\% 20$ endelig\%20rapport \%20desember\%202017\%20(2).pdf (Accessed February 8, 2018).

Mann, K. (2009). Transforming employer responsibilities: the privatisation of occupational pensions, Journal of Comparative Social Welfare 25(2):139-146. doi: https://doi.org/ 10.1080/17486830902789764.

Mares, I. (2001). Firm and the welfare state: when, why, and how does social policy matter to employers? In: P. A. hall \& D. Soskice (eds.) Varieties of Capitalism: The Institutional Foundations of Comparative Advantage, New York: Oxford University press.

Mares, I. (2003). The sources of business interest in social insurance: sectoral versus national differences, World Politics 55(1): 229-258. doi: https://doi.org/10.1353/wp.2003.0012.

McCarthy, D. (2006). The rationale for occupational pensions, Oxford Review of Economic Policy 22 (1): 57-65. doi: https://doi.org/10.1093/oxrep/gri004.

Midtsundstad, T. (2014). Flexible retirement in Norway. Working paper presented at the workshop 'Flexible Retirement Following the Scandinavian Model', German Bundestag, Berlin, 1. December 2014. Available from: https://www.researchgate.net/publication/278006153 Flexible retirement in Norway

Midtsundstad, T. (2004). Hvor mange har rett til AFP? [Coverage of AFP]. Working paper 2004:04, Oslo: Fafo Institute for Labour and Social Research.

Midtsundstad, T. \& Hippe, J. M. (2005). Pensjoner i arbeidsmarkedet [Labour market based pensions], I H. Torp (ed.), Nytt arbeidsliv. Medvirkning, inkludering og belønning, Oslo: Gyldendal Akademisk.

Midtsundstad, T. \& Hyggen, C. (2011). Pensjoner på børs - valg og risiko. [Pensions at the stock market - risk and behaviour]. Working paper 2011:05, Oslo: Fafo Institute for Labour and Social Research.

Natali, D., Keune, M. Pavollini, E. \& Seeleib-Kaiser, M. (2018). Sixty years after Titmuss: New findings on occupational welfare in Europe, Soc Policy Admin 52(2):435-448. doi: https://doi.org/10.1111/spol.12375.

Nergaard, K. (2010). Hvem har ikke AFP? En analyse med basis i registerbaserte data [Who are not entitled to AFP? An analyse based on register data], Working-paper 2009: 20, Oslo: Fafo Institute for Labour and Social Research.

OECD (2012). Pensions Outlook 2012, Paris: OECD.

OECD (2017). Pension at a Glance 2017, Paris: OECD.

Pavolini, E. \& Seeleib-Kaiser, M. (2018). Comparing occupational welfare in Europe: the case of occupational pensions, Soc Policy Admin 52(2): 477-490. doi: https://doi.org/10.1111/ spol.12378.

Pedersen, A. W. (2000). The Coverage of Occupational Pensions in Norway. Results from a Survey of Private Sector Companies, working-paper 2000: 23, Oslo: Fafo Institute for Labour and Social Research.

Schalev, M. (1996). The Privatization of Social Policy? Occupational Welfare and the Welfare State in America, Scandinavia and Japan, Basingstoke: Macmillian. 
Seeleib-Kaiser, M., Saunders, A. \& Naczyk, M. (2012). Shifting the public-private mix: a new dualization of welfare? In P. Emmenegger, S. Häusermann, B. Palier \& M. Seeleib-Kaiser (eds.) The Age of Dualization: the Changing Face of Inequality in Deindustrializing Societies, New York and Oxford: Oxford University Press.

Trampusch, C. (2009). Collective agreements on pensions as a source of solidarity, Journal of Comparative Social Welfare 25(2): 99-107. doi: https://doi.org/10.1080/17486830 902789715.

Trampusch, C. (2013). Employers and collectively negotiated occupational pensions in Sweden, Denmark and Norway: promoters, vacillators and adversaries, European Journal of Industrial Relations 19(1): 37-53. doi: https://doi.org/10.1177/095968011247 4882.

Trampusch, C. \& Eichenberger, P. (2012). Skills and industrial relations in coordinated marked economies: continuing vocational training in Denmark, the Netherlands, Austria, and Switzerland, British Journal of Industrial Relations 50(4): 644-66. doi: https://doi. org $/ 10.1177 / 0958928715611006$.

Veland, G. (2014). Tjenestepensjonsmarkedet 2001-2013 [The Norwegian Market of Occupational Pensions 2001-2013], working-paper 2014:11, Oslo: Fafo Institute for Labour and Social Research.

Wi $\beta$, T. (2016). From welfare states to welfare sectors: explaining sectoral differences in occupational pensions with economic and political power of employees, Journal of European Social Policy 25(5): 489-504. doi: https://doi.org/10.1177/0958928715611006.

\section{Notes}

${ }^{1}$ The AFP scheme covers around half of all private sector employees (Nergaard 2009) but almost $80 \%$ of employees older than 60 (Midtsundstad 2004).

${ }^{2}$ The minimum pension level (garantipensjonen) is after May 1, 2018, equal to NOK 194 192 for a single person (approximately 19,800 euros).

${ }^{3}$ Minimum contribution rate is $2 \%$. Up to 2013 , the maximum rate was up to $8 \%$ of income between 6 and $12 \mathrm{G}$ - and $5 \%$ of income between 1 and $6 \mathrm{G}$. After that the maximum contribution rate was changed to $7 \%$ for all income up to $12 \mathrm{G}$, including a supplementary contribution of up to $18.1 \%$ of income between 7.1 and $12 \mathrm{G}$ (i.e., maximum of $25.1 \%$ ). 